Article

\title{
Effects of Aloe arborescens Whole Plant Homogenate on Lipid Metabolism, Inflammatory Conditions and Liver Function of Dairy Cows during the Transition Period
}

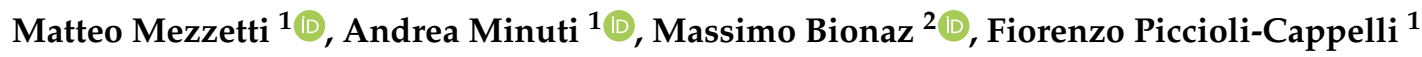 \\ and Erminio Trevisi ${ }^{1, *(D)}$ \\ 1 Department of Animal Sciences, Food and Nutrition (DIANA), Facoltà di Scienze Agrarie, \\ Alimentari e Ambientali, Università Cattolica del Sacro Cuore, 29122 Piacenza, Italy; \\ matteo.mezzetti@unicatt.it (M.M.); andrea.minuti@unicatt.it (A.M.); Fiorenzo.piccioli@unicatt.it (F.P.-C.) \\ 2 Department of Animal and Rangeland Sciences, Oregon State University, Corvallis, OR 97331, USA; \\ massimo.bionaz@oregonstate.edu \\ * Correspondence: erminio.trevisi@unicatt.it; Tel.: +39-0523-599278; Fax: +39-0523-599276
}

Received: 8 May 2020; Accepted: 22 May 2020; Published: 25 May 2020

Simple Summary: This study highlights the positive effect of an Aloe arborescens Mill. whole plant homogenate on the liver and renal function of dairy cows during the peripartum period. Such positive effects could depend on both anti-hyperlipidemic and anti-inflammatory effects of Aloe that could have mitigated hepatic stresses that typically occur in early lactation. Our findings suggest Aloe arborescens supplementation to be an effective strategy to ameliorate adverse metabolic conditions in transition cows, indicating it as a preventive nutraceutical strategy against metabolic disorders.

Abstract: The anti-hyperlipidemic and anti-inflammatory effects exerted by Aloe on monogastric mammals suggest it as a potential strategy to address the tremendous metabolic alterations that affect dairy cows during their transition to calving. A group of 20 multiparous Italian Holstein dairy cows were housed in freestalls and allocated into two homogeneous groups to receive either $200 \mathrm{~g} / \mathrm{d}$ of water (CTR) or $200 \mathrm{~g} /$ day of Aloe arborescens Mill. whole plant homogenate through a rumen tube (AAM) between -14 and 14 days from calving (DFC). From -14 to 35 DFC, the BCS, and milk yield were measured, and blood samples were collected to assess the hematochemical profile. Data underwent ANOVA testing using a mixed model for repeated measurements, including the treatment and time and their interactions as fixed effects. Compared to CTR cows, AAM cows had a less pronounced BCS loss in early lactation $(p<0.01)$, indicating less mobilization of body reserves. Compared to CTR cows, AAM cows had a lower plasma concentration of nonesterified fatty acids and beta hydroxybutyrate ( $p<0.01$ and $=0.01$ respectively) that, paired with the lower butterfat content and fat/protein ratio in their milk ( $p=0.03$ and $<0.01$ respectively), indicates that Aloe reduced the mobilization of body fats. AAM cows had a reduced concentration of myeloperoxidase in plasma and a lower SCC in milk compared to CTR cows ( $p=0.02$ for both), indicating an anti-inflammatory effect of Aloe. Furthermore, AAM cows had a lower plasma concentration of ceruloplasmin $(p<0.05)$ and higher plasma concentration of cholesterol, retinol, and paraoxonase compared to CTR cows $(p<0.01,<0.01$ and $<0.05$ respectively), indicating Aloe was effective in mitigating the acute phase response in early lactation. Finally, AAM cows had lower plasma creatinine concentrations around calving $(p<0.05)$, a lower concentration of plasma bilirubin, and a higher concentration of plasma tocopherol compared to CTR cows ( $p=0.01$ for both). These data suggest Aloe has anti-hyperlipidemic and anti-inflammatory effects on transition dairy cows that could have ameliorated liver and kidney function disruption and increased the availability of body antioxidants in early lactation. 
Keywords: acute phase response; anti-hyperlipidemic; anti-inflammatory; kidney function; nutraceutical

\section{Introduction}

The transition period (TP) is the most critical phase of a dairy cow's life [1,2]. Alterations in energy metabolism in this phase lead to a massive mobilization of lipid resources [3] that is often accompanied by systemic inflammation $[4,5]$. These phenomena result in impaired liver function $[6,7]$ and alter the redox balance in early lactation $[8,9]$.

For millennia, Aloe has been used in human medicine in both topical and oral applications $[10,11]$ due to its therapeutic proprieties [12,13] and positive effects on inflammation [14-16] and energy metabolism [17]. Previous research attributed such positive effects to many active compounds in both the inner leaf and leaf parenchyma of Aloe plants [18,19]. Aloin A is the most studied active compound of Aloe and is well known for its antioxidant, antimicrobial, anti-inflammatory, immune-stimulant, and anti-bacterial properties $[19,20]$. Previous experiments, which fed up to $1000 \mathrm{mg} / \mathrm{kg}$ body weight of Aloe barbadensis juice extract to murine models for 7 days, suggested the possible use of high dosages without negative effects on liver and kidney functions [21]. Similar experiments performed on diabetic rats [22] found Aloe to exert anti-diabetic effects by improving plasma insulin and reducing blood glucose concentration in fasting conditions and to manage dyslipidemia by restoring normal levels of lipoproteins and normal fatty acid composition in the liver and kidney. Other studies confirmed such an anti-hyperlipidemic effect [23] and found Aloe to reduce lipid peroxidation, inducing regenerative histological changes in the liver and kidney of diabetic rats [24].

Although previous experiments have been mostly performed on monogastric animals, these positive effects on energy metabolism and liver function suggest Aloe supplementation as a potential strategy to optimize the transition to calving in dairy cows. In a previous experiment [25], an Aloe arborescens Mill. whole plant homogenate (WPH) was ineffective in altering rumen fermentation in vitro, and no effect was detected on feed digestibility and feed intake when supplemented to dairy cows as a drench. However, in the same experiment, Aloin A was detected in the blood of dairy cows as early as $2 \mathrm{~h}$ after administration. The lack of any negative effect on feeding behavior, paired with the absorption of bioactive compounds into the blood, opened a new perspective on the use of Aloe spp. as a feed supplement in dairy cows, encouraging further investigation of the effects the plant exerts on dairy cow metabolism. We hypothesize that Aloe spp. has a positive effect on energy metabolism and inflammation and, as a consequence, improves performance and liver function in early lactation. We assess our hypothesis by supplementing dairy cows between -14 and 14 days from calving (DFC) with a drench of $200 \mathrm{~g} / \mathrm{d}$ of Aloe arborescens Mill. to assess the effects on body condition score (BCS) gain, milk yield (MY), milk composition, and blood profile.

\section{Materials and Methods}

\subsection{Experimental Design and Animal Management}

The trial was carried out at the Università Cattolica del Sacro Cuore research dairy barn (Cerzoo Experiment Station, San Bonico, Piacenza, Italy) in accordance with Italian laws on animal experimentation (DL n. 116, 27 January 1992) and ethics (authorization of the Italian Ministry of Health N 65427; 29 October 2010-PR). From October 2014 to April 2015, a group of 20 multiparous Italian Holstein dairy cows (number of lactations: $3.1 \pm 1.2$; body weight: $711 \pm 53 \mathrm{~kg}$; BCS: $2.51 \pm 0.28$; MY in the last lactation: 12,005 $\pm 1384 \mathrm{~kg}$; average lactation length: $350 \pm 51 \mathrm{~d}$ [mean $\pm \mathrm{SD}$ ]) were enrolled during their dry period and moved to a close-up packed pen 1 month before they were expected to calve. After calving, cows were immediately moved to an early lactation freestall pen until the end of the experiment. 
All cows were milked twice a day at 0130 and 1330. Animals were fed a total mixed ration (TMR), formulated in accordance with NRC (2001) [26] protein requirements and with INRA (1989) [27] energy requirements (Table 1 ).

Table 1. Composition and characteristics on a daily basis of the experimental diets fed to cow during dry and lactation periods.

\begin{tabular}{lcc}
\hline & Dry Period & Lactation Period \\
\hline & Item, \%DM \\
\hline Corn silage & 25.0 & 33.5 \\
Corn grain & - & 17.2 \\
Alfalfa hay & - & 15.3 \\
Grass hay & 51.6 & 3.5 \\
Soybean meal & 7.3 & 9.2 \\
Corn flakes & - & 7.4 \\
Sunflower meal & - & 2.4 \\
Corn gluten meal & - & 1.7 \\
Supplement ${ }^{1}$ & 1.0 & 2.1 \\
Cotton seeds & - & 7.7 \\
Wheat straw & 15.3 & - \\
\hline & Chemical composition & \\
\hline NEL, Mcal/kg of DM & 1.36 & 1.54 \\
Crude protein, \% DM & 12.50 & 16.00 \\
Starch + sugar, \%DM & 12.50 & 29.80 \\
Ether extract, \%DM & 2.70 & 4.50 \\
NDF, \%DM & 54.9 & 33.70 \\
\hline
\end{tabular}

${ }^{1} 42.9 \% \mathrm{Ca}_{2} \mathrm{PO}_{4} ; 28.6 \%$ urea; $14.3 \% \mathrm{MgO} ; 7.1 \% \mathrm{NaCl} ; 7.1 \%$ mineral vitamin supplement. The supplement for dry cows was composited to provide 1,500,000 UI/ $\mathrm{kg}$ of vitamin A, 150,000 IU/ $\mathrm{kg}$ of vitamin D3, $7000 \mathrm{UI} / \mathrm{kg}$ of vitamin $\mathrm{E}, 1100 \mathrm{mg} / \mathrm{kg}$ of $\mathrm{Mn}, 4000 \mathrm{mg} / \mathrm{kg}$ of Zn, $500 \mathrm{mg} / \mathrm{kg}$ of $\mathrm{Cu}, 70 \mathrm{mg} / \mathrm{kg}$ of I, $10 \mathrm{mg} / \mathrm{kg}$ of $\mathrm{Co}$ and $23 \mathrm{mg} / \mathrm{kg}$ of Se. The supplement for lactating cows was composited to provide 150,000 UI of vitamin A, 10,000 IU of vitamin D3, 200 $\mathrm{mg}$ of vitamin E, $100 \mathrm{mg}$ of vitamin $\mathrm{K}, 100 \mathrm{mg}$ of vitamin H1, $50 \mathrm{mg}$ of vitamin B1, $0.5 \mathrm{mg}$ of vitamin B12, $500 \mathrm{mg}$ of vitamin PP, $4000 \mathrm{mg}$ of choline, $350 \mathrm{mg}$ of $\mathrm{Mn}, 800 \mathrm{mg}$ of $\mathrm{Zn}, 40 \mathrm{mg}$ of $\mathrm{Cu}, 20 \mathrm{mg}$ of I, $1 \mathrm{mg}$ of Co and $1 \mathrm{mg}$ Se.

The TMR was distributed once daily at 0830 and 1030 for lactating and dry cows, respectively. A 3\% to $5 \%$ refusal was guaranteed to ensure cows had ad-libitum access to feed. Representative samples of hay, corn silage, and concentrate were collected monthly. Samples were pooled and analyzed to assess the chemical composition of the feed, as previously described [25]. Analysis results were used to calculate the nutritional values of feed, in accordance with NRC (2001) guidelines [26]. Cows were allocated to one of two homogeneous groups, one receiving $200 \mathrm{~g} /$ day of water (CTR) and one receiving $200 \mathrm{~g} /$ day of Aloe arborescens Mill. WPH between -14 and 14 DFC (AAM). Each dose of WPH was defrosted with warm water $\left(37^{\circ} \mathrm{C}\right)$ before use and water supplemented to the CTR group was heated at the same temperature. Both treatments were administered with a rumen tube before the morning feeding. Periodical checks were performed between -14 and 35 DFC, as shown in Figure 1 and described in the following sections.

\subsection{Aloe arborescens Mill. Whole Plant Homogenate Preparation}

Whole plants of Aloe arborescens Mill. (Dester Gardens, Crociale di Manerba del Garda, BS, Italy) were cut and homogenized with a commercial vegetable cutter (model R6, Robot Coupe, Vincennes Cedex, France). Homogenate was immediately frozen in plastic bags, with no additives. Detailed methods for preparation and chemical composition of the Aloe arborescens Mill. WPH have been reported previously [25]. 


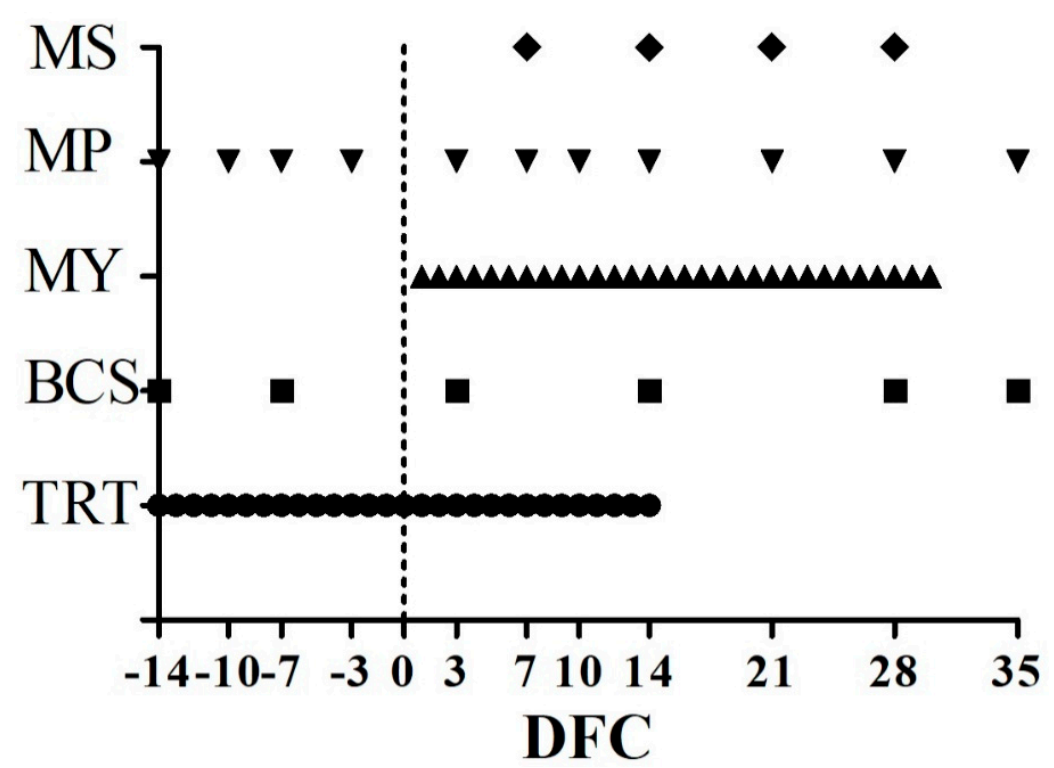

Figure 1. Scheduled time points, expressed as day from calving (DFC), for Aloe arborescens Mill. whole plant homogenate or placebo warm water administration (TRT), body condition score determination (BCS), and milk yield measurements (MY), blood sample collection for the metabolic profile (MP) and milk sample collection (MS).

\subsection{Body Condition Score and Milk Yield}

The BCS was determined by the same operator using a 1 to 4 scale (Agricultural Development and Advisory Service, 1986) at $-14,-7$ (SD $\pm 2 \mathrm{~d}$ in all the two time points), 3, 14, 28 and $35 \mathrm{DFC}$ ( $S D \pm 1 \mathrm{~d}$ in all the four time points). The MY was measured in the milking parlor by using the Afikim system (SAE Afikim, Kibbutz Afikim, Israele) at each milking between 1 and 30 DFC.

\subsection{Milk Sample Collection and Analysis}

Milk samples were collected from the morning milking at 7, 14, 21, and 28 DFC. The milk composition (fat, protein, lactose, casein content and titratable acidity) was assessed with infrared instrumentation (MilkoScan FT 120, Foss Analytics, Hillerød, Denmark), as previously reported [28]. The fat and protein yields and the fat to protein ratio were also calculated. Urea nitrogen was determined in skimmed milk by a spectrometric assay, using the urea nitrogen kit (cat. No. 0018255440, Instrumentation Laboratory, SpA, Milano, Italy) and the clinical autoanalyzer ILAB-650 (Instrumentation Laboratory, Lexington, Massachusetts, United States). The true protein value was calculated as the difference between the protein and urea nitrogen content. The somatic cell count (SCC) was determined using an optofluorometric method with an automated cell counter (Fossomatic 180, Foss Analytics, Hillerød, Denmark) and expressed as a linear score in accordance with Wiggans and Shook (1987) [29].

\subsection{Blood Sample Collection and Analysis}

Before the morning feeding, blood was collected from the jugular vein at -14 (before treatment administration), $-10,-7$ (SD $\pm 2 \mathrm{~d}$ in all the three time points), -3 ( $\pm 1 \mathrm{~d}), 3,7,10,14,21,28$ and $35 \mathrm{DFC}$ with 10-mL evacuated heparinized tubes (BD Vacutainer, BD Diagnostics, Franklin Lakes, NJ, USA). Samples were processed and analyzed in accordance with Calamari et al. (2016) [30].

A clinical autoanalyzer (ILAB-650, Instrumentation Laboratory, Lexington, MA, USA) was used to measure the concentration of glucose, non-esterified fatty acids (NEFA), beta hydroxybutyrate (BHB), urea, creatinine, $\mathrm{Ca}, \mathrm{Zn}$, haptoglobin, ceruloplasmin, total protein, albumin, globulin, cholesterol, total bilirubin, aspartate aminotransferase (AST-GOT) and gamma glutamyl transferase (GGT) according to Calamari et al. (2016) [30]. Furthermore, the same instrument was used to determine paraoxonase concentration according to Bionaz et al. (2007) [8], myeloperoxidase according to 
Bradley et al. (1982) [31], and total reactive oxygen metabolites (ROMt) according to Trevisi et al. (2015) [32]. Retinol, tocopherol, and $\beta$-carotene were analyzed by reverse-phase high-performance liquid chromatography (LC-4000, Jasco Europe, Carpi, MO, Italy) as previously described [32]. Further details on the analytical procedures adopted in blood analysis are reported in Table S1.

\subsection{Statistical Analysis}

Data were analyzed in SAS software, version 9.4 (SAS Inst. Inc., Cary, NC, USA) and are presented in graphs and tables as means and pooled standard error for individual means of treatments over time. Before analysis, the normality of distributions was verified for each parameter by reckoning the skewness and kurtosis according to the Shapiro test of SAS. Non-normally distributed parameters were normalized through natural logarithms (among plasma parameters: glucose, BHB, AST-GOT, and bilirubin concentrations; among milk parameters: butterfat, protein, and urea contents and the fat to protein ratio). Original values for log-transformed parameters are presented in Figure S1. Data on BCS, MY and milk and plasma parameters underwent ANOVA testing using a mixed model for repeated measures (Mixed Procedure, SAS Inst. Inc., Cary, NC, USA) in accordance with Littell et al. (1998) [33]. The statistical model included the fixed effect of the treatment (TRT) for CTR and AAM groups, time (considering a single DFC as a repeated measure for each cow) and the interaction of the two factors (TRT $\times$ time). The analysis was carried out using two covariance structures: autoregressive order and spatial power, with their heterogeneous counterparts. The compound symmetry has also been tested for parameters collected with equal-spaced time intervals. Covariance structures were ranked according to their Akaike information criterion, with the one having the lowest criterion being chosen [33]. A preliminary analysis was conducted on BCS and blood parameters. These were covariate using data collected at $-14 \mathrm{DFC}$ as the baseline, adopting $p \leq 0.1$ as a cutoff for covariate inclusion. None of the parameters had a significant covariate effect in the preliminary analysis and the covariate was thus removed from the final model. The pairwise comparison was done using the least significant difference test. Post-hoc comparisons were discussed when the $p$-value for the main effect was 0.05 or less. The main effects at $p \leq 0.1$ were discussed in the context of tendencies.

\section{Results}

\subsection{Body Condition Score and Milk Yield}

The BCS tended to be higher in AAM cows compared to CTR cows ( $p=0.06$; Figure 2a), and a TRT $\times$ time interaction was also observed $(p<0.01)$. Both groups had a similar BCS before calving and till 3 DFC, but the AAM cows had higher BCS than CTR cows from 14 DFC to the end of the experimental period ( $p<0.01$ at each time point). No difference between groups was detected for the MY (Figure 2b).

\subsection{Milk Quality Parameters}

Regarding milk quality parameters (Table 2), AAM cows had a lower butterfat content, fat/protein ratio and SCC compared to the CTR cows $(p=0.03, p<0.01$ and $p=0.02$, respectively) but higher casein content than CTR cows $(p=0.02)$. A TRT $\times$ time interaction was observed for the butterfat, fat output and fat/protein ratio ( $p=0.01, p=0.03$ and $p<0.01$, respectively), with AAM cows having the lowest values at 7 DFC $(p<0.01)$. No effect was detected for the other parameters. 

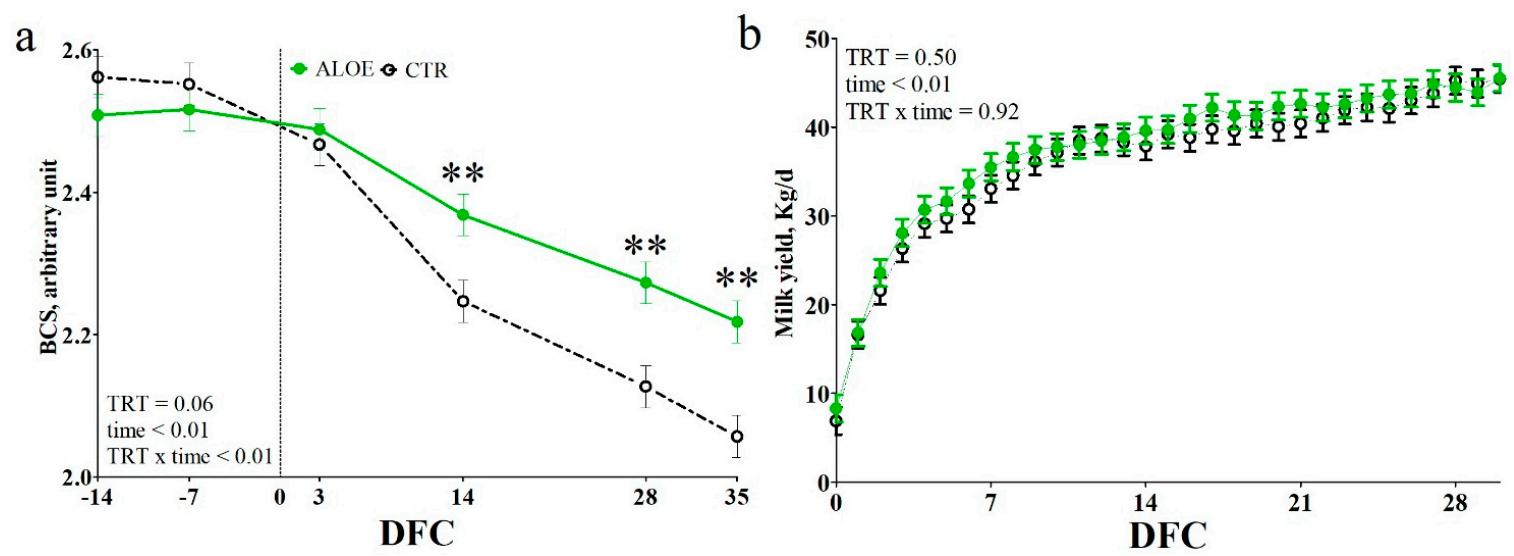

Figure 2. Values of BCS (a) and milk yield (b) in dairy cows receiving placebo water (CTR; black dotted line) or cows receiving a drench of $200 \mathrm{~g} / \mathrm{d}$ of Aloe arborescens Mill. whole plant homogenate between -14 and 14 days from calving (AAM; green solid line). ${ }^{* *}$ is $p<0.01$; DFC is days from calving.

Table 2. Milk composition and somatic cell count in control dairy cows or cows receiving $200 \mathrm{~g} / \mathrm{d}$ of Aloe arborescens Mill. homogenate extract as a drench between -14 and 14 days from calving.

\begin{tabular}{|c|c|c|c|c|c|c|c|c|c|}
\hline \multirow{2}{*}{ Item, Unit } & \multirow{2}{*}{ TRT $^{1}$} & \multicolumn{4}{|c|}{ Days From Calving } & \multirow{2}{*}{ SEM $^{2}$} & \multicolumn{3}{|c|}{$p$-Value } \\
\hline & & 7 & 14 & 21 & 28 & & TRT $^{1}$ & Time & TRT $\times$ Time ${ }^{3}$ \\
\hline Butterfat & CTR & 5.09 & 4.24 & 3.81 & 3.87 & 0.34 & 0.03 & 0.01 & 0.01 \\
\hline $\mathrm{mg} / 100 \mathrm{~mL}$ & AAM & $\underset{* *}{3.80}$ & 4.00 & 3.77 & 3.80 & & & & \\
\hline Fat output & CTR & 166.0 & 159.4 & 154.4 & 175.1 & 11.7 & 0.33 & 0.02 & 0.03 \\
\hline $\mathrm{g}$ & AAM & $\begin{array}{c}133.7 \\
* *\end{array}$ & 157.9 & 160.2 & 168.1 & & & & \\
\hline Total protein & CTR & 3.91 & 3.44 & 3.27 & 3.20 & 0.10 & 0.22 & $<0.01$ & 0.94 \\
\hline $\mathrm{mg} / 100 \mathrm{~mL}$ & AAM & 3.99 & 3.55 & 3.38 & 3.26 & & & & \\
\hline Protein output & CTR & 129.2 & 130.7 & 132.0 & 144.7 & 21.17 & 0.25 & 0.14 & 0.22 \\
\hline g & AAM & 141.1 & 139.9 & 143.8 & 144.4 & & & & \\
\hline Fat/protein ratio & CTR & 1.32 & 1.24 & 1.17 & 1.21 & 0.06 & $<0.01$ & 0.19 & $<0.01$ \\
\hline- & AAM & $\begin{array}{c}0.95 \\
* *\end{array}$ & 1.13 & 1.12 & 1.17 & & & & \\
\hline Lactose & CTR & 4.69 & 4.72 & 5.00 & 4.99 & 0.20 & 0.61 & 0.01 & 0.34 \\
\hline $\mathrm{mg} / 100 \mathrm{~mL}$ & AAM & 4.81 & 4.99 & 5.07 & 4.76 & & & & \\
\hline Caseins & CTR & 2.74 & 2.52 & 2.40 & 2.37 & 0.12 & 0.02 & $<0.01$ & 0.76 \\
\hline $\mathrm{mg} / 100 \mathrm{~mL}$ & AAM & 2.96 & 2.65 & 2.53 & 2.45 & & & & \\
\hline Titratable acidity & CTR & 4.23 & 3.53 & 3.34 & 3.24 & 0.24 & 0.68 & $<0.01$ & 0.49 \\
\hline${ }^{\circ} \mathrm{SH} / 50 \mathrm{~mL}$ & AAM & 4.09 & 3.64 & 3.52 & 3.44 & & & & \\
\hline Urea-N & CTR & 22.0 & 23.0 & 20.5 & 21.1 & 2.60 & 0.88 & 0.45 & 0.47 \\
\hline $\mathrm{mg} / \mathrm{dL}$ & AAM & 22.5 & 20.5 & 20.4 & 21.9 & & & & \\
\hline True protein ${ }^{4}$ & CTR & 3.69 & 3.21 & 3.06 & 2.99 & 0.10 & 0.22 & $<0.01$ & 0.87 \\
\hline $\mathrm{mg} / 100 \mathrm{~mL}$ & AAM & 3.77 & 3.34 & 3.18 & 3.04 & & & & \\
\hline Somatic cells count & CTR & 3.38 & 3.47 & 3.27 & 3.99 & 1.15 & 0.02 & 0.75 & 0.78 \\
\hline Linear score & AAM & 2.33 & 1.66 & 1.09 & 1.36 & & & & \\
\hline
\end{tabular}

${ }^{1}$ Treatment (CTR is cows receiving placebo water; AAM is cows receiving a drench of Aloe arborescens Mill.). ${ }^{2}$ Standard error $=$ larger standard error for the fixed effects. ${ }^{3}$ Treatment $\times$ time interaction $(* *$ is $p<0.01$ for differences among means within a column. These symbols are only presented when the interaction effect is significant). ${ }^{4}$ True protein $=$ total protein-(urea-N/100). 


\subsection{Metabolic Profile}

3.3.1. Energy and Protein Metabolism Biomarkers, Kidney Function Indicators and Mineral Metabolism Biomarkers

Among the energy metabolism biomarkers, glucose concentration was not affected by TRT (Figure S3a). The concentrations of NEFA and BHB were lower in the AAM cows than in the CTR cows $(p \leq 0.01$; Figure $3 a, b)$. Among the protein metabolism biomarkers, the urea concentration was not affected by TRT (Figure S3b). Among kidney function biomarkers, creatinine concentration had a significant TRT $\times$ time interaction $(p<0.01$; Figure $3 c)$. In comparison to CTR cows, the AAM cows had a lower creatinine concentration at -7 and -3 DFC ( $p<0.1$ and $p<0.05$, respectively) and a tendency toward higher creatinine concentration at 28 DFC $(p<0.1)$. Mineral concentration did not differ between the two groups (Figure S3c,d).
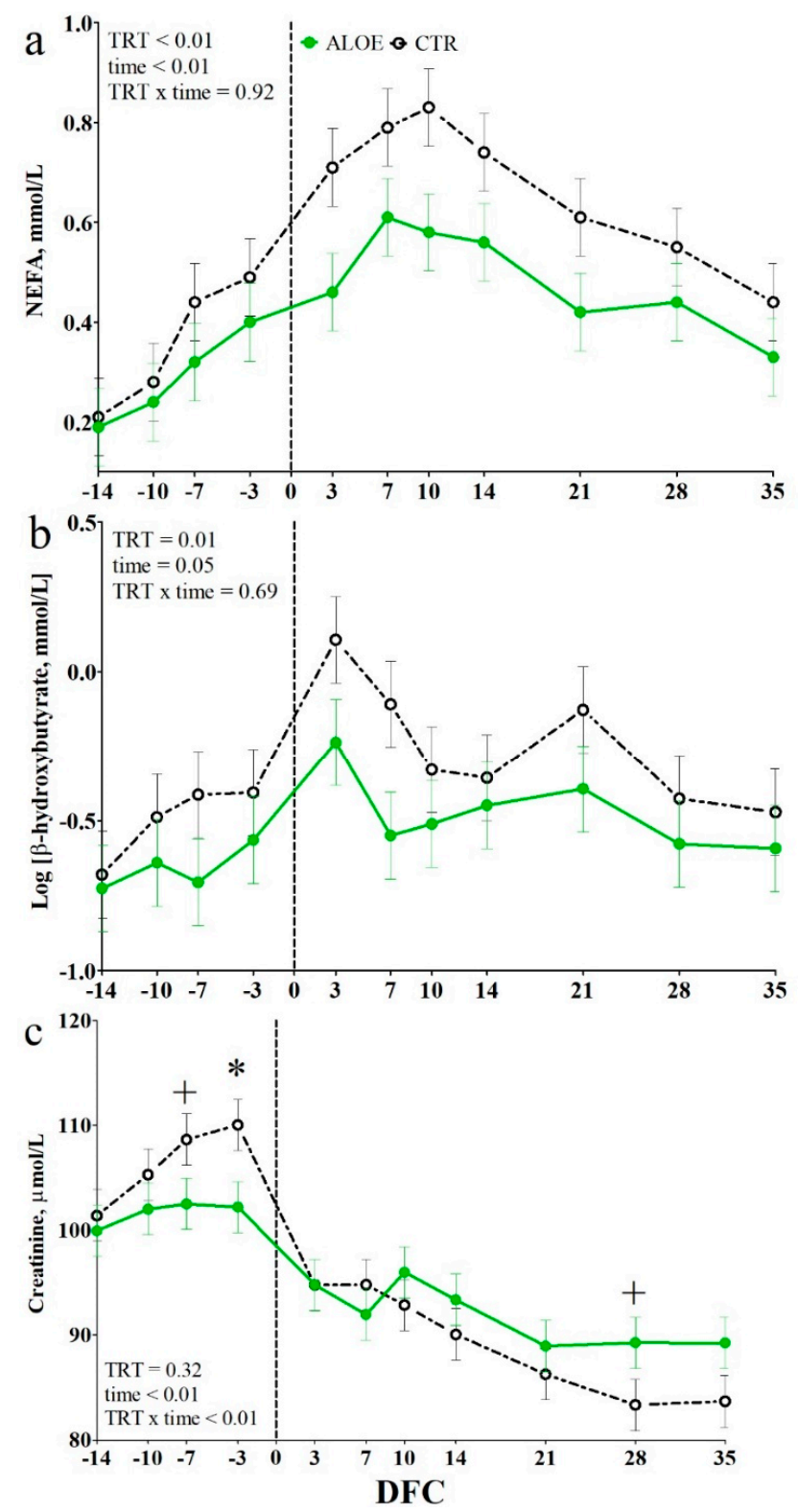

Figure 3. Time course of plasma concentrations of non-esterified fatty acids. NEFA (a), beta-hydroxybutyrate (b), and creatinine (c) in dairy cows receiving placebo water (CTR; black dotted 
line) or cows receiving a drench of $200 \mathrm{~g} / \mathrm{d}$ of Aloe arborescens Mill. whole plant homogenate between -14 and 14 days from calving (AAM; green solid line). ${ }^{*}$ is $p<0.05 ;+$ is $p<0.1$; Log indicates data expressed as log-transformed; DFC is days from calving.

\subsubsection{Liver Function and Inflammation Biomarkers}

Among liver function biomarkers, total bilirubin concentration was affected by TRT and the TRT $\times$ time interaction $(p<0.01$ and $p=0.04$ respectively; Figure $4 \mathrm{a})$; it was lower in the AAM cows than in the CTR cows between -3 DFC and the end of the experimental period. The GGT concentration had a tendency toward a TRT $\times$ time effect $(p=0.06$; Figure S3e) and was numerically higher in the AAM cows than in the CTR cows before calving. AST-GOT was not affected by TRT (Figure S3f).
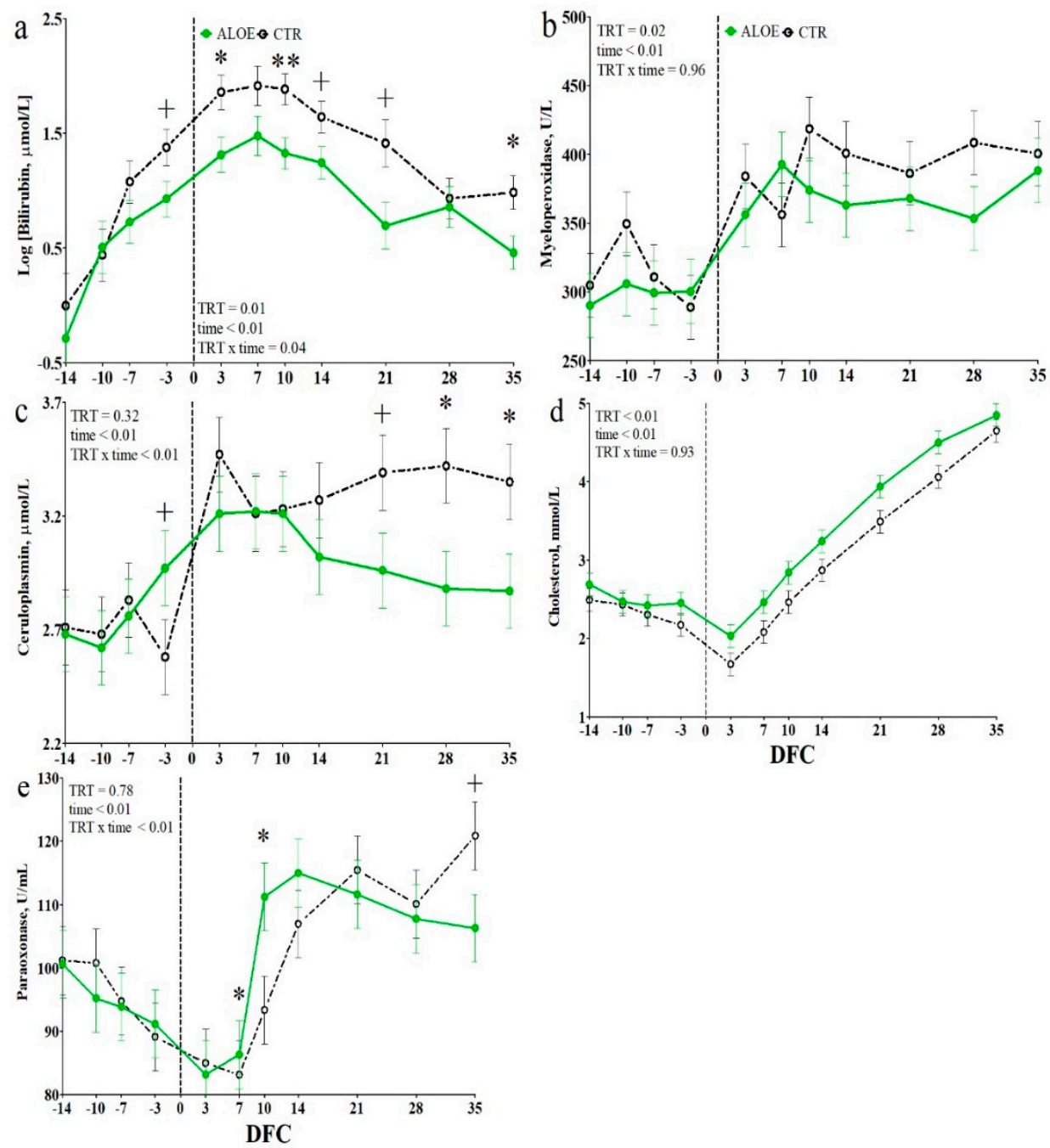

Figure 4. Time course of plasma concentrations of bilirubin (a), myeloperoxidase (b), ceruloplasmin (c), cholesterol (d) and paraoxonase (e) in dairy cows receiving placebo water (CTR; black dotted line) or cows receiving a drench of $200 \mathrm{~g} / \mathrm{d}$ of Aloe arborescens Mill. whole plant homogenate between -14 and 14 days from calving (AAM; green solid line). ${ }^{* *}$ is $p<0.01$; ${ }^{*}$ is $p<0.05$; + is $p<0.1$; Log indicates data expressed as log-transformed; DFC is days from calving.

Among the inflammation biomarkers, the concentration of myeloperoxidase was lower in the AAM cows compared with the CTR cows $(p=0.02$; Figure $4 b)$. No effect was detected for total protein and globulin (Figure S3g,h). Among the positive acute-phase proteins (APP), no effect was detected for the haptoglobin level (Figure S3i), whereas ceruloplasmin had a TRT $\times$ time interaction $(p<0.01$; 
Figure 4c). Compared to the CTR cows, AAM cows had lower ceruloplasmin concentration from 21 DFC to the end of the experimental period ( $p<0.05$ at each time point). Among the negative APPs, levels of cholesterol and retinol were higher in the AAM cows than in the CTR cows $(p<0.01$; Figure $4 \mathrm{~d}$ or Figure 5a), whereas paraoxonase concentration had a TRT $\times$ time interaction $(p<0.01$; Figure $4 \mathrm{e})$ resulting in higher levels in the AAM cows than in the CTR cows at 7 and 10 DFC $(p<0.05)$. No difference between groups was detected for albumin (Figure S3j).
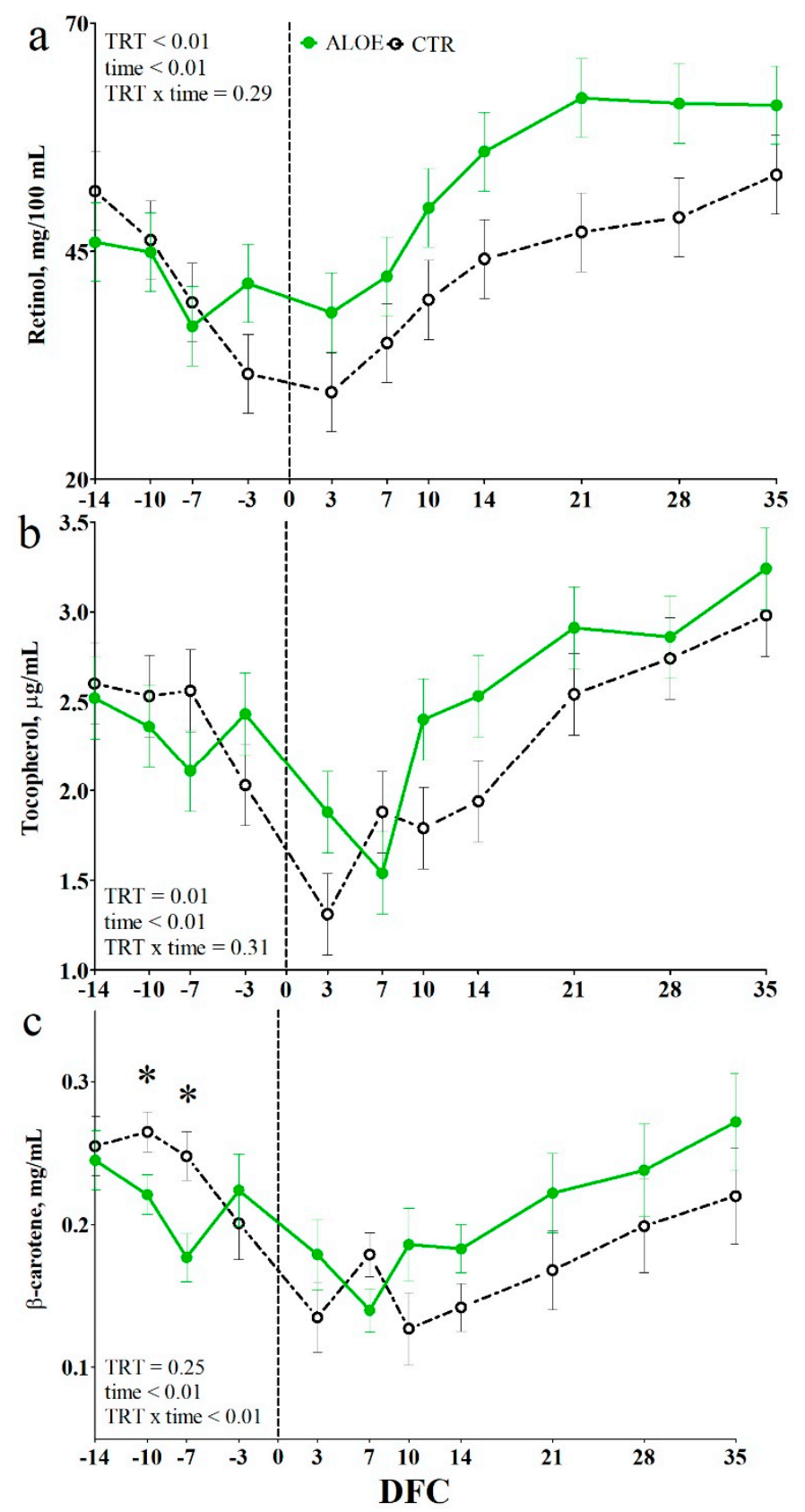

Figure 5. Time course of plasma concentrations of retinol (a), tocopherol (b), and $\beta$-carotene (c) in dairy cows receiving placebo water (CTR; black dotted line) or cows receiving a drench of $200 \mathrm{~g} / \mathrm{d}$ of Aloe arborescens Mill. whole plant homogenate between -14 and 14 days from calving (AAM; green solid line). ${ }^{*}$ is $p<0.05 ;$ DFC is days from calving. 


\subsubsection{Redox Balance Biomarkers}

The concentration of tocopherol was higher in the AAM cows than in the CTR cows ( $p=0.01$, Figure $5 b)$, whereas $\beta$-carotene level was affected by a TRT $\times$ time interaction $(p<0.01$, Figure $5 c)$ and was lower in the AAM cows than in the CTR cows at -10 and -7 DFC $(p<0.05)$. Concentrations of ROMt were not different between groups (Figure S3k).

\section{Discussion}

\subsection{Aloe Reduced Mobilization of Body Reserves and Improved Lipid Metabolism in Transition Period}

A negative energy balance is known to affect transition dairy cows, leading to the sudden mobilization of body reserves [3]. The less-marked BCS loss in our AAM cows compared to CTR cows suggests WPH mitigated mobilization processes in early lactation. This is supported by the lower NEFA level found in the plasma of our AAM cows, reflecting a less-marked mobilization of lipid resources [34]. The reduced mobilization of body fats found in our study is consistent with the reduction in triglycerides and free fatty acids found in the plasma, liver, and kidney of murine models of Streptozotocin-induced diabetes and Letrozole-induced polycystic ovarian syndrome after feeding with Aloe barbadensis ethanolic extract [22,23]. Although obtained in murine models and using Aloe barbadensis instead of Aloe arborescens, these anti-hyperlipidemic effects observed against diabetes and polycystic ovary syndrome-related dyslipidemia suggests that the reduced NEFA concentration in the blood of our early lactating cows could depend on the effectiveness of WPH in managing body fat mobilization.

Phytosterols contained in Aloe gel, such as lonophenol and cycloartenol, are peroxisome proliferator-activated receptor alpha $(\operatorname{PPAR} \alpha)$ and peroxisome proliferator-activated receptor gamma $(\operatorname{PPAR} \gamma)$ agonists in monogastric animals [35], and also emodin is known to activate PPAR $\gamma$ [36]. Although the content of these compounds in our WPH has not been assessed and their effective absorption in blood has never been investigated, most of the effects of Aloe in our transition cows are consistent with the activation of PPAR signaling; these effects are supported by previous results in murine models $[17,23,24]$. PPAR $\gamma$ plays a critical role in controlling lipolysis, although the driving mechanism of such interaction is still not fully elucidated. On one hand, the key lipolytic enzyme adipose triglyceride lipase (ATGL) is a PPAR $\gamma$ target gene [37]; however, lipolysis is inhibited during adipogenesis [38], which is mostly driven by activation of PPAR $\gamma$ [39]. Thus, there are two possible mechanisms by which PPAR $\gamma$ inhibits lipolysis in adipose tissue: It increases insulin sensitivity [40], which potently inhibits lipolysis [38], and it decreases the activity of ATGL via perilipin, a PPAR $\gamma$ target [41]. The reduction of NEFA observed in our study can also be driven by the activation of PPAR $\alpha$. This transcription factor is known to control the expression of genes involved in the entry of NEFA into mitochondria [42]. Thus, we can speculate that the lower NEFA level in our AAM cows could partially depend on faster removal from the bloodstream paired with an increased insulin sensitivity affected by several secondary compounds present in Aloe, as recently reviewed [43].

In dairy cows, a NEFA overload in the liver could impair the $\beta$-oxidation process [44,45], leading to the release of ketone bodies (as BHB) in the blood [34].The lower BHB level in the blood of our AAM cows could thus result from their lower amount of circulating NEFA, but it could also partially depend on the effectiveness of Aloe in restoring the normal activity of lipid-metabolizing enzymes [23], which could have improved the oxidative power of the liver in oxidizing NEFA. This effect is also consistent with the activation of PPAR $\alpha$ driven by Aloe components, which is known to increase fatty acid catabolism by improving $\beta$-oxidation $[46,47]$.

Such positive effects of WPH on lipid metabolism are consistent with the lower butterfat, fat output, and fat to protein ratio in the milk of our AAM cows compared to CTR cows; both NEFA and BHB are known to directly contribute to the de novo synthesis of milk fat $[48,49]$. Despite trends of BCS, NEFA, BHB, and milk fat detected in our AAM cows suggest a direct effect of Aloe compounds on lipid metabolism, the lack of individual feed intake and plasma insulin concentration measurements must be pointed out as a limitation of our experimental design. Thus, further investigations including individual 
feed intake measurement, energy balance calculation, plasma insulin concentration assessment, glucose tolerance test in peripheral tissues, and liver biopsies are required to confirm that lower lipid mobilization found in our cows receiving Aloe is driven by a direct effect in ameliorating lipid metabolism through improving insulin sensitivity and NEFA removal from the bloodstream rather than a positive effect on mitigating the negative energy balance through improving feed intake.

\subsection{Aloe Improved Kidney Function in Late Gestation and Mitigated the Acute Phase Response and Improved Liver Function in Early Lactation}

Cows in early lactation are physiologically affected by an acute phase response in the liver [6,50]. During the acute phase, the liver shifts its anabolic priorities; the plasmatic trends of the APPs reflect the severity of the phenomenon [51]. Ceruloplasmin is known as a positive APP, and typically its plasma concentration increases when an acute phase response occurs [52]. Conversely, paraoxonase, lipoproteins, and retinol-binding protein are labeled negative APP because their plasma concentrations typically decrease during an acute phase response [4,8]. The faster decrease in ceruloplasmin and the higher concentration of paraoxonase, cholesterol (as an index of lipoprotein) and retinol (reflecting the plasma trends of retinol-binding protein) observed in AAM cows in early lactation suggest a less inflammatory-like condition or a faster resolution of the acute phase response compared to CTR cows [53]. The less-marked acute phase response in AAM cows fits with the activation of PPARs driven by Aloe, as PPARs are potent negative regulators of the acute phase response in different species, including cattle [47]. Such a negative regulation could be a result of an anti-inflammatory effect exerted by Aloe through interacting with $\operatorname{PPAR} \gamma$, as suggested by the lower SCC paired with the lower plasma myeloperoxidase concentration.

Immune dysfunction in dairy cows during the TP could lead to uncontrolled inflammation, and such inflammatory conditions are known to worsen the acute phase response in the liver once lactation starts $[50,54,55]$. The SCC is a widely accepted indicator for local inflammations because it reflects the migration of leukocytes to cope with microbial invasions in the udder [56]. PPAR $\gamma$ is known to downregulate the production of pro-inflammatory cytokines involved in the recruitment of leukocytes to the mammary gland [57], partially accounting for the beneficial effect exerted by Aloe in reducing SCC. This is supported by the downregulated expression of the chemoattractant of neutrophils interleukin 8 in mammary macrophages observed in LPS-stimulated human macrophages incubated with Aloe [58]. The shift from a pro- to an anti-inflammatory phenotype induced in white blood cells by PPAR $\gamma$ activation could also account for the lower myeloperoxidase concentration found in the blood of our AAM cows compared to CTR cows. Myeloperoxidase is involved in the generation of reactive oxygen species in neutrophils [59], and its plasma concentration could thus serve as a reliable marker of inflammation in the bloodstream. Thus, the reduction of local inflammation could have reduced the likelihood of development of systemic inflammation, as reflected by the lower myeloperoxidase levels found in the blood.

An impairment of renal glomerular filtration rate has been reported in late gestation in many different species, including ruminants [60], and the massive utilization of amino acids for gluconeogenesis could concur in renal dysfunction of dairy cows during the late gestation [61]. Recent studies performed on monogastric models and humans found high levels of circulating pro-inflammatory cytokines (i.e., tumor necrosis factor alpha, interleukin 1) released during excessive lipid mobilization and uncontrolled inflammation to induce renal artery endothelial dysfunction [62-64], thus suggesting also high circulating NEFA and systemic inflammations occurring in dairy cows during TP to play a pivotal role in inducing renal dysfunctions in late gestation. Creatinine is related to phosphocreatine utilization during normal muscular activity, and the hematic concentration of this metabolite serves as a reliable index of glomerular filtration efficiency, as it reflects the capacity of the kidneys to remove it [65]. Thus, lower levels of plasma creatinine found in AAM cows before calving suggests WPH has improved their renal glomerular filtration rate as compared to CTR cows, deposing for a positive effect of Aloe on kidney function, probably induced by its anti-hyperlipidemic 
and anti-inflammatory actions. Similarly, the liver function of cows in early lactation is commonly impaired by an overload of NEFA and by the acute phase response [45,53]. Positive effects exerted by Aloe on lipid metabolism and inflammatory conditions could thus account for the reduced bilirubin levels found post-partum in the blood of AAM cows compared to CTR cows, indicating improved liver function. Bilirubin is the result of the degradation of red blood cells, and increased concentrations of bilirubin in the blood indicate reduced clearance activity by liver enzymes [66].

Such positive effects of Aloe in restoring liver and kidney function have been previously reported by Adesokan et al. (2010) and Ramachandraiahgari et al. (2012) [21,24], who observed regenerative liver and kidney histological changes in rats with Streptozotocin-induced diabetes receiving Aloe barbadensis or its polysaccharides. More recently, Saka et al. (2011), Nahar et al. (2013), and Koo et al. (2019) [67-69] observed a reduction of bilirubin in rats and humans receiving Aloe treatments. The reduction of bilirubin before parturition in AAM cows appears to indicate more direct activity of Aloe on bilirubin clearance in the liver. The transcription of the main enzyme involved in the conjugation of bilirubin, uridine $5^{\prime}$-diphospho-glucuronosyltransferase, is under the control of several nuclear receptors, including PPAR. Prior studies have determined that phytosterols present in Aloe vera are potent PPAR $\alpha$ and PPAR $\gamma$ agonists, as observed in grivet kidney cells and confirmed in mouse liver [35]. Thus, the reduction in bilirubin observed in our study is likely due to a transcriptomic effect of Aloe vera phytosterols in the liver via PPAR activation.

Higher tocopherol concentrations found in the blood of AAM cows is not surprising, considering the high level of this vitamin in Aloe leaf [70], although positive effects exerted by WPH in mitigating the acute phase response and improving liver function could have contributed to higher tocopherol levels. Tocopherol is known to serve as a secondary antioxidant, reducing the chain propagation and amplification of lipid peroxidation [71], and a massive depletion of body stocks of this vitamin (as well as other antioxidant systems) is known to occur in early lactating cows [72,73]. The liver plays a pivotal role in reducing antioxidant compounds when they have scavenged free radicals and other oxidant species in the body [72,73], and lipoproteins are the main carrier of tocopherol in blood [74]. Thus, both a positive effect of Aloe on the activity of liver antioxidant enzymes [24], which could have improved the recovery of oxidized tocopherol, and a greater availability of lipoproteins (as suggested by the higher cholesterol level found in AAM cows), which could have improved the circulation of this vitamin in the blood, could have contributed to higher concentrations of circulating tocopherol in AAM cows compared to CTR cows. Such increased tocopherol availability could have benefited udder health, also accounting for the lower SCC in the milk of cows receiving Aloe found in our study. Tocopherol is known to directly regulate tissue integrity, improving the tightness of the Furstenberg's rosette at the teat end, and thus being beneficial in mastitis control [75].

\section{Conclusions}

In our study, the reduced level of NEFA and BHB in the blood of cows receiving Aloe is consistent with their reduced milk fat and could account for their reduced mobilization of body fats and reduced ketogenesis; these effects could be driven by greater efficiency in the oxidation of NEFA at the liver level. The reduced mobilization of body fat in AAM vs. CTR cows, together with the less-marked acute phase response in early lactation, could partly account for the reduced bilirubin level, reflecting improved liver function. Although high concentrations of vitamin E in Aloe leaf could largely account for the greater availability of blood tocopherol found in AAM cows in early lactation, ameliorated disruption of liver function could have improved management of antioxidant systems by liver enzymes in this phase, partially accounting for such an effect.

Overall, our data suggest a role for PPARs activation in the metabolic effects exerted by Aloe on transition dairy cows. Effects on lipid metabolism are consistent with the activation of PPAR $\gamma$ on adipose tissue and activation of PPAR $\alpha$ at the liver level. The positive effects on acute phase indicators could depend on an anti-inflammatory effect of Aloe driven by the activation of both PPAR isotypes. Although the interaction between minor Aloe compounds and PPARs has already been demonstrated, 
an in-depth study is required to confirm the absorption of these secondary compounds into the blood. Furthermore, a study taking a transcriptome approach to investigate the alterations induced by Aloe on pathways related to energy metabolism and inflammation could highlight the effect of the different compounds in Aloe on PPARs activation.

Supplementary Materials: The following are available online at http://www.mdpi.com/2076-2615/10/5/917/s1, Table S1: Intra- and inter-assay coefficient of variations, limit of quantification (LOQ), codes of commercial kits used and references for their validation in the bovine plasma for plasma parameters included in the study. Figure S1: Pattern of plasmatic concentrations of glucose (a), beta hydroxybutyrate (b), glutamate-oxaloacetate transaminase (AST-GOT; (c) and bilirubin (d) expressed as their original values in dairy cows receiving placebo water (CTR; black dotted line) or cows receiving a drench of $200 \mathrm{~g} / \mathrm{d}$ of Aloe arborescens Mill. whole plant homogenate between -14 and 14 days from calving (AAM; green solid line). DFC is days from calving. Figure S2: Pattern of plasmatic concentrations of glucose (a), beta hydroxybutyrate (b), glutamate-oxaloacetate transaminase (AST-GOT; (c) and bilirubin (d) expressed as their original values in dairy cows receiving placebo water (CTR; black dotted line) or cows receiving a drench of $200 \mathrm{~g} / \mathrm{d}$ of Aloe arborescens Mill. whole plant homogenate between -14 and 14 days from calving (AAM; green solid line). DFC is days from calving.

Author Contributions: Conceptualization, M.B., M.M., A.M. and E.T.; methodology, A.M. and E.T.; formal analysis M.M. and A.M.; investigation, M.M.; resources, E.T.; data curation, M.M. and A.M.; writing-original draft preparation, M.M.; writing-review and editing, M.B., A.M. and E.T.; supervision, M.B. and E.T.; project administration, F.P.-C. and E.T.; funding acquisition, E.T. All authors have read and agreed to the published version of the manuscript.

Funding: This research was funded by the National Institute for Food, Agriculture and Forestry-MIPAAF ('ALBO' ID 67) and supported by CREI (Romeo and Enrica Invernizzi Research Center of the Università Cattolica del S. Cuore funded by the "Fondazione Romeo ed Enrica Invernizzi", Milan, Italy).

Conflicts of Interest: The authors declare no conflict of interest. The funders had no role in the design of the study; in the collection, analyses, or interpretation of data; in the writing of the manuscript, or in the decision to publish the results.

\section{References}

1. Mulligan, F.J.; Doherty, M.L. Production diseases of the transition cow. Vet. J. 2008, 176, 3-9. [CrossRef] [PubMed]

2. Van Knegsel, A.T.M.; Hammon, H.M.; Bernabucci, U.; Bertoni, G.; Bruckmaier, R.M.; Goselink, R.M.A.; Gross, J.J.; Kuhla, B.; Metges, C.C.; Parmentier, H.K.; et al. Metabolic adaptation during early lactation: Key to cow health, longevity and a sustainable dairy production chain. CAB Rev. Perspect. Agric. Vet. Sci. Nutr. Nat. Resour. 2014, 9, 1-15. [CrossRef]

3. Drackley, J.K. Biology of dairy cows during the transition period: The final frontier? J. Dairy Sci. 1999, 82, 2259-2273. [CrossRef]

4. Trevisi, E.; Amadori, M.; Cogrossi, S.; Razzuoli, E.; Bertoni, G. Metabolic stress and inflammatory response in high-yielding, periparturient dairy cows. Res. Vet. Sci. 2012, 93, 695-704. [CrossRef] [PubMed]

5. Minuti, A.; Bani, P.; Piccioli-Cappelli, F.; Uboldi, O.; Bacciu, N.; Trevisi, E. Metabolic and biochemical changes in plasma of the periparturient rabbit does with different litter size. Animal 2015, 9, 614-621. [CrossRef] [PubMed]

6. Bertoni, G.; Trevisi, E.; Han, X.; Bionaz, M. Effects of inflammatory conditions on liver activity in puerperium period and consequences for performance in dairy cows. J. Dairy Sci. 2008, 91, 3300-3310. [CrossRef] [PubMed]

7. Graugnard, D.E.; Moyes, K.M.; Trevisi, E.; Khan, M.J.; Keisler, D.; Drackley, J.K.; Bertoni, G.; Loor, J.J. Liver lipid content and inflammometabolic indices in peripartal dairy cows are altered in response to prepartal energy intake and postpartal intramammary inflammatory challenge. J. Dairy Sci. 2013, 96, 918-935. [CrossRef]

8. Bionaz, M.; Trevisi, E.; Calamari, L.; Librandi, F.; Ferrari, A.; Bertoni, G. Plasma paraoxonase, health, inflammatory conditions, and liver function in transition dairy cows. J. Dairy Sci. 2007, 90, 1740-1750. [CrossRef]

9. Sordillo, L.M.; Aitken, S.L. Impact of oxidative stress on the health and immune function of dairy cattle. Vet. Immunol. Immunopathol. 2009, 128, 104-109. [CrossRef] 
10. Grindlay, D.; Reynolds, T. The Aloe vera phenomenon: A review of the properties and modern uses of the leaf parenchyma gel. J. Ethnopharmacol. 1986, 16, 117-151. [CrossRef]

11. Menghini, A.; Boncompagni, E.; Fulceri, S.; Occhionero, G. Il Valore dell'aloe: Storia, Coltivazione, Moderni Impieghi Salutistici; Aboca Edizioni: Sansepolcro (AR), Italy, 2005; ISBN 978-88-95642-20-8.

12. Vázquez, B.; Avila, G.; Segura, D.; Escalante, B. Antiinflammatory activity of extracts from Aloe vera gel. J. Ethnopharmacol. 1996, 55, 69-75. [CrossRef]

13. Chandan, B.K.; Saxena, A.K.; Shukla, S.; Sharma, N.; Gupta, D.K.; Suri, K.A.; Suri, J.; Bhadauria, M.; Singh, B. Hepatoprotective potential of Aloe barbadensis Mill. against carbon tetrachloride induced hepatotoxicity. J. Ethnopharmacol. 2007, 111. [CrossRef] [PubMed]

14. Davis, R.H.; Maro, N.P. Aloe vera and gibberellin. Anti-inflammatory activity in diabetes. J. Am. Podiatr. Med. Assoc. 1989, 79, 1-4. [CrossRef] [PubMed]

15. Davis, R.H.; Rosenthal, K.Y.; Cesario, L.R.; Rouw, G.A. Processed Aloe vera administered topically inhibits inflammation. J. Am. Podiatr. Med. Assoc. 1989, 79, 395-397. [CrossRef] [PubMed]

16. Davis, R.H.; Leitner, M.G.; Russo, J.M.; Byrne, M.E. Anti-inflammatory activity of Aloe vera against a spectrum of irritants. J. Am. Podiatr. Med. Assoc. 1989, 79, 263-276. [CrossRef]

17. Rajasekaran, S.; Sivagnanam, K.; Ravi, K.; Subramanian, S. Hypoglycemic effect of Aloe vera gel on streptozotocin-induced diabetes in experimental rats. J. Med. Food 2004, 7, 61-66. [CrossRef]

18. Agarry, O.; Olaleye, M.T.; Bello-Michael, C.O. Comparative antimicrobial activities of aloe vera gel and leaf. Afr. J. Biotechnol. 2005, 4, 1413-1414.

19. Lucini, L.; Pellizzoni, M.; Pellegrino, R.; Molinari, G.; Colla, G. Phytochemical constituents and in vitro radical scavenging activity of different Aloe species. Food Chem. 2015, 170, 501-507. [CrossRef]

20. Gutterman, Y.; Chauser-Volfson, E. The distribution of the phenolic metabolites barbaloin, aloeresin and aloenin as a peripheral defense strategy in the succulent leaf parts of Aloe arborescens. Biochem. Syst. Ecol. 2000, 28, 825-838. [CrossRef]

21. Adesokan, A.A.; Oyewole, O.I.; Turay, B.M.S. Kidney and Liver Function Parameters in Alloxan-Induced Diabetic Rats Treated with Aloe Barbadensis Juice Extract. Sierra Leone J. Biomed. Res. 2010, 1. [CrossRef]

22. Rajasekaran, S.; Ravi, K.; Sivagnanam, K.; Subramanian, S. Beneficial effects of Aloe vera leaf gel extract on lipid profile status in rats with Streptozotocin diabetes. Clin. Exp. Pharmacol. Physiol. 2006, 33, 232-237. [CrossRef] [PubMed]

23. Nampoothiri, L.P.; Desai, B.N.; Maharjan, R.H. Aloe barbadensis Mill. formulation restores lipid profile to normal in a letrozole-induced polycystic ovarian syndrome rat model. Pharmacogn. Res. 2012, 4, 109. [CrossRef] [PubMed]

24. Ramachandraiahgari, R.M.Y.; Somesula, S.R.; Adi, P.J.; Mannur, I.S.; Enamala, M.; Matcha, B. Protective role of ethanolic extract of Aloe vera antioxidant properties on liver and kidney of streptozotocin-induced diabetic rats. Dig. J. Nanomater. Biostructures 2012, 1, 175-184.

25. Bani, P.; Grossi, P.; Lucini, L.; Pellizzoni, M.; Minuti, A.; Trevisi, E. Administration of Aloe arborescens homogenate to cattle: Interaction with rumen fermentation and gut absorption of aloin. Ital. J. Anim. Sci. 2016, 15, 233-240. [CrossRef]

26. NRC. Nutrient Requirement of Dairy Cattle, 7th ed.; National Academies Press: Washington, DC, USA, 2001; ISBN 9780309069977.

27. INRA. Ruminant Nutrition: Recommended Allowances and Feed Tables; Jarrige, R., Ed.; John Libbey: London, UK, 1989.

28. Chessa, S.; Bulgari, O.; Rizzi, R.; Calamari, L.; Bani, P.; Biffani, S.; Caroli, A.M. Selection for milk coagulation properties predicted by Fourier transform infrared spectroscopy in the Italian Holstein-Friesian breed. J. Dairy Sci. 2014, 97, 4512-4521. [CrossRef]

29. Wiggans, G.R.; Shook, G.E. A lactation measure of somatic cell count. J. Dairy Sci. 1987, 70, $2666-2672$. [CrossRef]

30. Calamari, L.; Ferrari, A.; Minuti, A.; Trevisi, E. Assessment of the main plasma parameters included in a metabolic profile of dairy cow based on Fourier Transform mid-infrared spectroscopy: Preliminary results. BMC Vet. Res. 2016, 12, 4. [CrossRef]

31. Bradley, P.P.; Priebat, D.A.; Christensen, R.D.; Rothsein, G. Measurement of cutaneous inflammation: Estimation of neutrophil content with an enzyme marker. J. Investig. Dermatol. 1982, 78, 206-209. [CrossRef] 
32. Trevisi, E.; Jahan, N.; Bertoni, G.; Ferrari, A.; Minuti, A. Pro-inflammatory cytokine profile in dairy cows: Consequences for new lactation. Ital. J. Anim. Sci. 2015, 14, 285-292. [CrossRef]

33. Littell, R.C.; Henry, P.R.; Ammerman, C.B. Statistical analysis of repeated measures data using SAS procedures. J. Anim. Sci. 1998, 76, 1216. [CrossRef]

34. Herdt, T.H. Ruminant adaptation to negative energy balance. Influences on the etiology of ketosis and fatty liver. Vet. Clin. North Am. Food Anim. Pract. 2000, 16, 215-230. [CrossRef]

35. Nomaguchi, K.; Tanaka, M.; Misawa, E.; Yamada, M.; Toida, T.; Iwatsuki, K.; Goto, T.; Kawada, T. Aloe vera phytosterols act as ligands for PPAR and improve the expression levels of PPAR target genes in the livers of mice with diet-induced obesity. Obes. Res. Clin. Pract. 2011, 5, e190-e201. [CrossRef]

36. Shou, X.; Zhou, R.; Zhu, L.; Ren, A.; Wang, L.; Wang, Y.; Zhou, J.; Liu, X.; Wang, B. Emodin, a chinese herbal medicine, inhibits reoxygenation-induced injury in cultured human aortic endothelial cells by regulating the peroxisome proliferator-activated receptor- $\gamma$ (PPAR- $\gamma$ ) and endothelial nitric oxide synthase (eNOS) signaling pathway. Med. Sci. Monit. 2018, 24, 643-651. [CrossRef] [PubMed]

37. Kershaw, E.E.; Schupp, M.; Guan, H.-P.; Gardner, N.P.; Lazar, M.A.; Flier, J.S. PPAR $\gamma$ regulates adipose triglyceride lipase in adipocytes in vitro and in vivo. Am. J. Physiol. Metab. 2007, 293, E1736-E1745. [CrossRef] [PubMed]

38. Frühbeck, G.; Méndez-Giménez, L.; Fernández-Formoso, J.-A.; Fernández, S.; Rodríguez, A. Regulation of adipocyte lipolysis. Nutr. Res. Rev. 2014, 27, 63-93. [CrossRef] [PubMed]

39. Lee, J.-E.; Schmidt, H.; Lai, B.; Ge, K. Transcriptional and Epigenomic Regulation of Adipogenesis. Mol. Cell. Biol. 2019, 39. [CrossRef]

40. Wang, Q.; Imam, M.U.; Yida, Z.; Wang, F. Peroxisome Proliferator-Activated Receptor Gamma (PPAR $\gamma$ ) as a Target for Concurrent Management of Diabetes and Obesity-Related Cancer. Curr. Pharm. Des. 2017, 23. [CrossRef]

41. Nakamura, M.T.; Yudell, B.E.; Loor, J.J. Regulation of energy metabolism by long-chain fatty acids. Prog. Lipid Res. 2014, 53, 124-144. [CrossRef]

42. Sharma, S.; Sun, X.; Rafikov, R.; Kumar, S.; Hou, Y.; Oishi, P.E.; Datar, S.A.; Raff, G.; Fineman, J.R.; Black, S.M. PPAR- $\gamma$ regulates carnitine homeostasis and mitochondrial function in a lamb model of increased pulmonary blood flow. PLoS ONE 2012, 7. [CrossRef]

43. Kumar, R.; Singh, A.K.; Gupta, A.; Bishayee, A.; Pandey, A.K. Therapeutic potential of Aloe vera-A miracle gift of nature. Phytomedicine 2019, 60, 152996. [CrossRef]

44. Loor, J.J.; Dann, H.M.; Guretzky, N.A.J.; Everts, R.E.; Oliveira, R.; Green, C.A.; Litherland, N.B.; Rodriguez-Zas, S.L.; Lewin, H.A.; Drackley, J.K. Plane of nutrition prepartum alters hepatic gene expression and function in dairy cows as assessed by longitudinal transcript and metabolic profiling. Physiol. Genom. 2006, 27, 29-41. [CrossRef] [PubMed]

45. Loor, J.J.; Everts, R.E.; Bionaz, M.; Dann, H.M.; Morin, D.E.; Oliveira, R.; Rodriguez-Zas, S.L.; Drackley, J.K.; Lewin, H.A. Nutrition-induced ketosis alters metabolic and signaling gene networks in liver of periparturient dairy cows. Physiol. Genom. 2007, 32, 105-116. [CrossRef] [PubMed]

46. Cappon, G.D.; Liu, R.C.M.; Frame, S.R.; Hurtt, M.E. Effects of the rat hepatic peroxisome proliferator, Wyeth 14,643, on the lactating goat. Drug Chem. Toxicol. 2002, 25, 255-266. [CrossRef]

47. Bionaz, M.; Chen, S.; Khan, M.J.; Loor, J.J. Functional role of PPARs in ruminants: Potential targets for fine-tuning metabolism during growth and lactation. PPAR Res. 2013, 2013, 1-28. [CrossRef] [PubMed]

48. Emery, R.S. Deposition, secretion, transport and oxidation of fat in ruminants. J. Anim. Sci. 1979, 48, 1530-1537. [CrossRef] [PubMed]

49. Åkerlind, M.; Holtenius, K.; Bertilsson, J.; Emanuelson, M. Milk composition and feed intake in dairy cows selected for high or low milk fat percentage. Livest. Prod. Sci. 1999, 59, 1-11. [CrossRef]

50. Trevisi, E.; Minuti, A. Assessment of the innate immune response in the periparturient cow. Res. Vet. Sci. 2018, 116, 47-54. [CrossRef]

51. Castell, J.V.; Gómez-Lechón, M.J.; David, M.; Andus, T.; Geiger, T.; Trullenque, R.; Fabra, R.; Heinrich, P.C. Interleukin-6 is the major regulator of acute phase protein synthesis in adult human hepatocytes. FEBS Lett. 1989, 242, 237-239. [CrossRef]

52. Ceciliani, F.; Ceron, J.J.; Eckersall, P.D.; Sauerwein, H. Acute phase proteins in ruminants. J. Proteom. 2012, 75, 4207-4231. [CrossRef] 
53. Bertoni, G.; Trevisi, E. Use of the liver activity index and other metabolic variables in the assessment of metabolic health in dairy herds. Vet. Clin. North Am. Food Anim. Pract. 2013, 29, 413-431. [CrossRef]

54. Trevisi, E.; Zecconi, A.; Bertoni, G.; Piccinini, R. Blood and milk immune and inflammatory profiles in periparturient dairy cows showing a different liver activity index. J. Dairy Res. 2010, 77, 310-317. [CrossRef] [PubMed]

55. Jahan, N.; Minuti, A.; Trevisi, E. Assessment of immune response in periparturient dairy cows using ex vivo whole blood stimulation assay with lipopolysaccharides and carrageenan skin test. Vet. Immunol. Immunopathol. 2015, 165, 119-126. [CrossRef] [PubMed]

56. Pillai, S.R.; Kunze, E.; Sordillo, L.M.; Jayarao, B.M. Application of Differential Inflammatory Cell Count as a Tool to Monitor Udder Health. J. Dairy Sci. 2001, 84, 1413-1420. [CrossRef]

57. Perdomo, M.C.; Santos, J.E.; Badinga, L. Trans-10, cis-12 conjugated linoleic acid and the PPAR- $\gamma$ agonist rosiglitazone attenuate lipopolysaccharide-induced TNF- $\alpha$ production by bovine immune cells. Domest. Anim. Endocrinol. 2011, 41, 118-125. [CrossRef] [PubMed]

58. Budai, M.M.; Varga, A.; Milesz, S.; Tőzsér, J.; Benkő, S. Aloe vera downregulates LPS-induced inflammatory cytokine production and expression of NLRP3 inflammasome in human macrophages. Mol. Immunol. 2013, 56, 471-479. [CrossRef] [PubMed]

59. Faith, M.; Sukumaran, A.; Pulimood, A.B.; Jacob, M. How reliable an indicator of inflammation is myeloperoxidase activity? Clin. Chim. Acta 2008, 396, 23-25. [CrossRef]

60. Van Drongelen, J.; De Vries, R.; Lotgering, F.K.; Smits, P.; Spaerman, M.E.A. Functional vascular changes of the kidney during pregnancy in animals: A systematic review and meta-analysis. PLoS ONE 2014, 9, e112084. [CrossRef]

61. Bell, A.W.; Burhans, W.S.; Overton, T.R. Protein nutrition in late pregnancy, maternal protein reserves and lactation performance in dairy cows. Proc. Nutr. Soc. 2000, 59, 119-126. [CrossRef]

62. Ma, S.; Zhu, X.-Y.; Eirin, A.; Woollard, J.R.; Jordan, K.L.; Tang, H.; Lerman, A.; Lerman, L.O. Perirenal fat promotes renal arterial endothelial dysfunction in obese swine through tumor necrosis factor- $\alpha$. J. Urol. 2016, 195, 1152-1159. [CrossRef]

63. Aragno, M.; Cutrin, J.C.; Mastrocola, R.; Perrelli, M.-G.; Restivo, F.; Poli, G.; Danni, O.; Boccuzzi, G. Oxidative stress and kidney dysfunction due to ischemia/reperfusion in rat: Attenuation by dehydroepiandrosterone. Kidney Int. 2003, 64, 836-843. [CrossRef]

64. Carlsson, A.C.; Larsson, T.E.; Helmersson-Karlqvist, J.; Larsson, A.; Lind, L.; Ärnlöv, J. Soluble TNF Receptors and Kidney Dysfunction in the Elderly. J. Am. Soc. Nephrol. 2014, 25, 1313-1320. [CrossRef] [PubMed]

65. Zoccali, C.; Maio, R.; Tripepi, G.; Mallamaci, F.; Perticone, F. Inflammation as a mediator of the link between mild to moderate renal insufficiency and endothelial dysfunction in essential hypertension. J. Am. Soc. Nephrol. 2006, 4, S64-S68. [CrossRef] [PubMed]

66. Rodriguez-Jimenez, S.; Haerr, K.J.; Trevisi, E.; Loor, J.J.; Cardoso, F.C.; Osorio, J.S. Prepartal standing behavior as a parameter for early detection of postpartal subclinical ketosis associated with inflammation and liver function biomarkers in peripartal dairy cows. J. Dairy Sci. 2018, 101, 8224-8235. [CrossRef] [PubMed]

67. Saka, W.A.; Akhigbe, R.E.; Ishola, O.S.; Ashamu, E.A.; Olayemi, O.T.; Adeleke, G.E. Hepatotherapeutic Effect of Aloe Vera in Alcohol-induced Hepatic Damage. Pak. J. Biol. Sci. 2011, 14, 742-746. [CrossRef] [PubMed]

68. Nahar, T.; Uddin, B.; Hossain, S.; Sikder, A.M.; Ahmed, S. Aloe vera gel protects liver from oxidative stress-induced damage in experimental rat model. J. Complement. Integr. Med. 2013, 10, 1-7. [CrossRef] [PubMed]

69. Koo, H.J.; Lee, K.R.; Kim, H.S.; Lee, B.-M. Detoxification effects of aloe polysaccharide and propolis on the urinary excretion of metabolites in smokers. Food Chem. Toxicol. 2019, 130, 99-108. [CrossRef]

70. Ozsoy, N.; Candoken, E.; Akev, N. Antioxidative activity, total phenols, flavonoids, ascorbic acid, $\beta$-carotene, $\alpha$-tocopherol in Aloe vera. Oxid. Med. Cell. Longev. 2009, 2, 99-106. [CrossRef]

71. Ghiselli, A.; Serafini, M.; Maiani, G.; Azzini, E.; Ferro-Luzzi, A. A fluorescence-based method for measuring total plasma antioxidant capability. Free Radic. Biol. Med. 1995, 18, 29-36. [CrossRef]

72. Celi, P. Oxidative stress in ruminants. In Studies on Veterinary Medicine. Oxidative Stress in Applied Basic Research and Clinical Practice; Mandelker, L., Vajdovich, P., Eds.; Humana Press: Totowa, NJ, USA, 2011; pp. 191-231. ISBN 978-1-61779-070-6.

73. Celi, P.; Gabai, G. Oxidant/antioxidant balance in animal nutrition and health: The role of protein oxidation. Front. Vet. Sci. 2015, 2. [CrossRef] 
74. Behrens, W.A.; Thompson, J.N.; Madère, R. Distribution of $\alpha$-tocopherol in human plasma lipoproteins. Am. J. Clin. Nutr. 1982, 35, 691-696. [CrossRef]

75. McDowell, L.R.; Williams, S.N.; Hidiroglou, N.; Njeru, C.A.; Hill, G.M.; Ochoa, L.; Wilkinson, N.S. Vitamin E supplementation for the ruminant. Anim. Feed Sci. Technol. 1996, 60, 273-296. [CrossRef]

(C) 2020 by the authors. Licensee MDPI, Basel, Switzerland. This article is an open access article distributed under the terms and conditions of the Creative Commons Attribution (CC BY) license (http://creativecommons.org/licenses/by/4.0/). 